\title{
Techniques for Absorption into Indonesian and the Acceptance of Loan Words Related to Covid-19: Socioterminology Approach
}

\section{Lalu Muhamad Helmi', Mahsun Mahsun², Burhanuddin Burhanuddin ${ }^{3}$}

Universitas Mataram, West Nusa Tenggara, Indonesia

Universitas Mataram, West Nusa Tenggara, Indonesia

Universitas Mataram, West Nusa Tenggara, Indonesia

\begin{tabular}{|c|c|}
\hline Article History & Abstract \\
\hline $\begin{array}{l}\text { Submitted date: } \\
\text { 2021-06-17 } \\
\text { Accepted date: } \\
\text { 2021-09-21 } \\
\text { Published date: } \\
\text { 2021-11-28 } \\
\text { Key words: } \\
\text { terms, Covid-19, } \\
\text { socioterminological } \\
\text { approach, matching rules, } \\
\text { acceptance of terms }\end{array}$ & $\begin{array}{l}\text { This study answers two questions: what equivalence rules of terms are dominantly } \\
\text { found in the absorption words during the Covid- } 19 \text { pandemic, and how acceptable } \\
\text { these terms are in the Indonesian-speaking community. The data were collected by } \\
\text { using documentation or observation method, supported by the use of a questionnaire } \\
\text { The data were analyzed by using intralingual equivalence and descriptive analysis } \\
\text { methods. The results show that } 33 \text { foreign terms were matched using translation } \\
\text { techniques, ten words with absorption techniques, and two words with combined } \\
\text { translation and absorption techniques. Furthermore, the acceptability of absorption } \\
\text { terms during the Corona virus pandemic is } 39 \% \text {, while } 61 \% \text { indicates the } \\
\text { unacceptability of absorption terms during the Corona virus pandemic. }\end{array}$ \\
\hline \multicolumn{2}{|r|}{ Abstrak } \\
\hline $\begin{array}{l}\text { istilah, Covid-19, } \\
\text { pendekatan } \\
\text { sosioterminologi, kaidah } \\
\text { pemadanan, dan } \\
\text { keberterimaan istilah }\end{array}$ & $\begin{array}{l}\text { Dalam penelitian ini, terdapat dua hal yang dijawab, yaitu kaidah pemadanan istilah } \\
\text { apa yang dominan digunakan pada istilah serapan dalam masa pandemi covid-19 dan } \\
\text { keberterimaan istilah-istilah tersebut di masyarakat tutur bahasa Indonesia. Metode } \\
\text { pengumpulan data yang digunakan adalah metode dokumentasi atau metode simak } \\
\text { ditunjang dengan penggunaan kuesioner. Metode analisis data yang digunakan yaitu } \\
\text { padan intralingual dan analisis deskriptif. Hasil penelitian menunjukkan terdapat } 33 \\
\text { istilah asing yang dipadankan menggunakan teknik penerjemahan, } 10 \text { istilah dengan } \\
\text { teknik penyerapan, dan } 2 \text { istilah dengan teknik gabungan penerjemahan dan } \\
\text { penyerapan. Selanjutnya, tingkat keberterimaan istilah serapan dalam masa pandemi } \\
\text { virus korona adalah sebanyak } 39 \% \text {, sedangkan } 61 \% \text { sisanya menunjukkan tingkat } \\
\text { ketidakberterimaan terhadap istilah serapan dalam masa pandemi virus korona. }\end{array}$ \\
\hline
\end{tabular}

\section{Pendahuluan}

Bahasa merupakan salah satu aspek fundamental dalam kehidupan manusia. Segala tindakan manusia dalam kehidupannya selalu bertalian erat dengan bahasa. Dalam hal relasi bahasa dengan masyarakat, kedua hal ini menunjukkan wujud hubungan yang bersifat resiprokal. Artinya, pada kondisi tertentu, perkembangan masyarakat dapat menghendaki perkembangan bahasa, dan di sisi lain, perkembangan bahasa, dapat juga mempengaruhi perkembangan masyarakat. Oleh karena

Corresponding author:

${ }^{1}$ 1mhelmyakbar@gmail.com 
Helmy, L. M., Mahsun, M \& Burhanuddin, B., (2021). Techniques for Absorption into Indonesian and the Acceptance of Loan Words Related to Covid-19: Socioterminology Approach. LITE: Jurnal Bahasa, Sastra, dan Budaya 17 (2), 139-149. https://doi.org/10.33633/lite.v17i2.4761

keadaan masyarakat yang tidak statis, bahasa takluk atas hukum perubahan itu. Salah satu bukti perubahan bahasa itu tampak pada aspek peristilahan.

Menurut Kridalaksana (2008), istilah merupakan kata atau gabungan kata yang dengan cermat mengungkapkan konsep, proses, keadaan, atau sifat yang khas dalam bidang tertentu. Pada masa pandemi Corona Virus Disease 2019 (Covid-19) terlihat bahwa bahasa mengalami perubahan. Fakta lingual ini dapat teridentifikasi melalui munculnya topik diskusi ruang publik berkisar ihwal penyakit virus korona berserta istilah-istilah yang mengikutinya seperti social distancing, corona suspect, dan hand sanitizer secara serentak. Istilah-istilah asing tersebut kemudian dibuatkan padanannya dalam bahasa Indonesia.

Jika dicermati dari konsep pemadanan istilah yang ada, sistem pemadanan istilah asing pada masa pandemi virus korona berbeda satu dengan yang lain. Sebagai contoh, istilah rapid test yang dipadankan dengan istilah uji cepat. Istilah ini menggunakan teknik pemadanan dengan penerjemahan. Data lain menunjukkan kenyataan yang berbeda, sebagai contoh istilah antiseptic yang dipadankan dengan istilah antiseptik. Istilah ini menggunakan teknik pemadanan dengan penyerapan.

Selain itu, bentuk padanan istilah asing yang telah dibakukan itupun belum tentu digunakan oleh penutur bahasa Indonesia. Fakta menunjukkan bahwa istilah asing masih lebih sering digunakan dibandingkan dengan padanan istilah yang telah dibentuk, sebagai contoh istilah Corona virus yang dipadankan menjadi virus korona. Sejak periode Maret 2020 sampai November 2020, data awal menunjukkan bahwa istilah corona virus digunakan sebanyak 3898 kali, sedangkan istilah virus korona sebanyak 205 kali. Faktor lain yang menyebabkan fenomena tersebut adalah terdapat bentukan istilah lain selain yang telah yang telah dipadankan, sebagai contoh istilah asing new normal yang dipadankan menjadi istilah kenormalan baru, tetapi istilah yang lazim digunakan di masyarakat adalah new normal atau normal baru.

Penelitian yang mempunyai relevansi dengan penelitian ini di antaranya Qodratillah (2004); Astuti (2007); Darnis (2012); Zaim (2015); Arifin (2018); Sirulhaq dkk. (2018); Darheni (2019); dan Wardani, Vera, dan Nuraiza (2019). Penelitian yang dilakukan Qodratillah (2004) bertujuan mengidentifikasi keseragaman pemakaian istilah di kalangan dokter, baik dengan orang seprofesi maupun dengan orang tak seprofesi serta keseragaman pemakaian istilah di kalangan profesional keuangan dengan orang seprofesi. Penelitian Astuti (2007) bermaksud mengetahui sikap dan penerimaan mahasiswa dan dosen terhadap istilah-istilah bahasa Indonesia, baik itu terjemahan maupun serapan. Penelitian Darnis (2012) merupakan tesis yang bertujuan mengulas hubungan antara kebermanfaatan kaidah pembentukan istilah, yaitu Pedoman Umum Pembentukan Istilah (PUPI) dengan keberterimaan istilah.

Selanjutnya, penelitian yang dilakukan oleh Zaim (2015) bertujuan mengungkapkan bagaimana penutur Indonesia menyerap kata asing dalam komunikasi bahasa Indonesia, dan sejauh mana kata serapan asing tersebut berterima dan bermanfaat bagi penutur Indonesia. Penelitian Arifin (2018) bertujuan mendeskripsikan keterbacaan terjemahan dan unsur serapan istilah-istilah teknologi informasi dari bahasa Inggris ke Indonesia. Penelitian yang dilakukan oleh Sirulhaq dkk. (2018) berusaha mengidentifikasi dan mengelaborasi kelemahan KBBI dilihat dari belum adanya bentuk potensial yang ada. Dengan kata lain, penelitian ini menekankan pentingnya bentuk yang potensial untuk dicantumkan sebagai kosakata bahasa Indonesia, tidak hanya mengadopsi kata-kata dari bahasa asing. Penelitian yang dilakukan oleh Darheni (2019) berhasil mengidentifikasi teknik penyerapan istilah asing dalam bidang otomotif dari aspek morfologis dan fonologis. Ditinjau dari segi morfologis, istilah asing dalam bidang otomotif dapat dibentuk melalui proses morfologis, yakni afiksasi, reduplikasi, dan abreviasi. Terakhir, penelitian yang dilakukan oleh Wardani, Vera, 
Helmy, L. M., Mahsun, M \& Burhanuddin, B., (2021). Techniques for Absorption into Indonesian and the Acceptance of Loan Words Related to Covid-19: Socioterminology Approach. LITE: Jurnal Bahasa, Sastra, dan Budaya 17 (2), 139-149. https://doi.org/10.33633/lite.v17i2.4761

dan Nuraiza (2019) bertujuan mendeskripsikan proses pemakaian kata serapan dan istilah asing dalam opini pada surat kabar harian Serambi Indonesia.

Penelitian yang memiliki homogenitas dengan penelitian ini memiliki kesamaan dalam aspek objek kajian yakni terminologi atau peristilahan. Perbedaan terdapat pada aspek subjek penelitian, populasi penelitian, dan sampel penelitian. Selain itu, penelitian relevan yang dipaparkan di atas hanya sampai kepada upaya mengidentifikasi teknik pemadanan istilah asing, namun tidak mengkaji kaitan dengan keberterimaan padanan istilah tersebut di masyarakat. Oleh karena itu, penelitian ini menjadi perlu dilakukan guna melengkapi dan menambah khazanah ilmu pengetahuan terkait bidang peristilahan.

Mencermati pokok masalah yang akan diuraikan dalam penelitian ini, penulis menggunakan beberapa teori yang akan dijelaskan pada bagian ini yaitu hakikat istilah serapan, penulisan unsur serapan, pedoman umum pembentukan istilah, dan pemadanan istilah. Berikut akan dijelaskan secara berurutan teori-teori tersebut.

Kata serapan adalah kata yang diserap dari bahasa lain berdasarkan kaidah bahasa penerima (kbbi.kemdikbud.go.id). Selanjutnya, Kridalaksana (2008), yang kemudian menamakan fenomena ini dengan kata pinjam atau borrowing, menyebutkan bahwa pinjaman merupakan pemasukan unsur fonologis, gramatikal, atau leksikal dalam bahasa atau dialek dari bahasa atau dialek lain karena kontak atau peniruan.

Dalam perkembangannya, bahasa Indonesia menyerap unsur dari berbagai bahasa, baik dari bahasa daerah seperti bahasa Jawa, bahasa Sunda, dan bahasa Bali, maupun dari bahasa asing, seperti bahasa Sansekerta, Arab, Portugis, Belanda, Cina, dan Inggris. Berdasarkan taraf integrasinya, unsur serapan dalam bahasa Indonesia dibagi ke dalam dua kelompok besar. Pertama, unsur asing yang belum sepenuhnya terserap ke dalam bahasa Indonesia. Kedua, unsur asing yang penulisan dan pengucapannya disesuaikan dengan kaidah bahasa Indonesia. Dalam hal ini, penyerapan diusahakan agar ejannya diubah seperlunya sehingga bentuk Indonesianya masih dapat dibandingkan dengan bentuk asalnya.

Menurut Mulyanto (2017), istilah adalah kata atau frasa yang dipakai sebagai nama atau lambang yang dengan cermat mengungkapkan makna, konsep, proses, keadaan, atau sifat khas dalam bidang ilmu pengetahuan, teknologi, dan seni. Selain itu, tata istilah atau terminologi yang termaktub dalam Mulyanto (2017) didefinisikan sebagai perangkat asas dan ketentuan pembentukan istilah serta kumpulan istilah yang dihasilkannya, sebagai contoh 'anabolisme', 'demokrasi', 'pasar modal', 'pemerataan', dan 'perang elektron'.

Pemadanan istilah asing ke dalam bahasa Indonesia (dan jika perlu ke dalam salah satu bahasa serumpun) dilakukan lewat penerjemahan, penyerapan, serta gabungan penerjemahan dan penyerapan. Demi keseragaman, sumber rujukan yang diutamakan adalah bahasa Inggris yang pemakaiannya bersifat internasional karena sudah lazim digunakan oleh para ahli di bidangnya. Penulisan istilah serapan itu dilakukan dengan atau tanpa penyesuaian ejaan berdasarkan kaidah fonotaktik, yakni hubungan urutan bunyi yang diizinkan dalam bahasa Indonesia.

\section{Metode}

Penelitian ini menggunakan pendekatan sosioterminologi. Menurut Tammerman (dalam Darnis, 2012), pendekatan sosioterminologi merupakan kajian tentang terminologi yang berkaitan dengan adat penggunaannya dalam masyarakat. Dalam penelitian ini, yang dimaksud dengan adat penggunaan terminologi adalah terminologi-terminologi serapan yang digunakan dalam masa pandemi virus korona.

Jika dikaitkan dengan aspek pengkajiannya, data dalam penelitian ini adalah istilah-istilah yang muncul dan berkaitan dengan dunia kesehatan di masa pandemi virus korona. Oleh karena itu, data 
Helmy, L. M., Mahsun, M \& Burhanuddin, B., (2021). Techniques for Absorption into Indonesian and the Acceptance of Loan Words Related to Covid-19: Socioterminology Approach. LITE: Jurnal Bahasa, Sastra, dan Budaya 17 (2), 139-149. https://doi.org/10.33633/lite.v17i2.4761

yang dimaksud dalam penelitian ini mengacu pada semua tuturan yang mengandung istilah-istilah di masa pandemi.

Selanjutnya, dalam rangka mengumpulkan data yang dimaksud di atas, ditempuh tiga tahapan strategis ihwal metode pengumpulan data, yaitu dokumentasi atau metode simak ditunjang dengan penggunaan kuesioner. Metode simak digunakan untuk menyimak keberterimaan dan kebermanfaatan padanan istilah serapan pada masa pandemi virus korona yang digunakan oleh sampel penelitian (responden) dalam bentuk bahasa tulis. Hal ini sesuai dengan pendapat Mahsun (2017) bahwa metode simak atau istilah menyimak tidak hanya berkaitan dengan penggunaan bahasa secara lisan, tetapi juga penggunaan bahasa secara tertulis.

Selanjutnya, guna memaksimalkan tahapan pengumpulan data, penelitian juga ditunjang dengan penyebaran kuesioner. Menurut Mahsun (2017), kuesioner merupakan metode pengumpulan data yang digunakan untuk memperoleh data yang lebih terstruktur dan terperinci dari sejumlah besar informan yang dipandang representatif mewakili populasi penelitian. Oleh karena itu, kuesioner tersebut mengandung sejumlah pertanyaan. Adapun metode analisis data yang digunakan yaitu metode padan intraligual seperti yang disarankan Mahsun (2017), serta metode agih (Sudaryanto, 2018), dan metode deskriptif analisis. Di tahap analisis data, metode padan intralingual digunakan untuk menganalisis dan mengelompokkan teknik pemadanan istilah yang digunakan pada istilah-istilah asing di masa pandemi virus korona.

Selanjutnya, metode analisis data yang digunakan adalah analisis deskriptif. Menurut Sugiyono, (2018) analisis deskriptif adalah suatu metode yang berfungsi untuk mendeskripsikan atau memberi gambaran terhadap objek yang diteliti melalui data atau sampel yang telah terkumpul sebagaimana adanya tanpa melakukan analisis dan membuat kesimpulan yang berlaku untuk umum atau generalisasi. Dalam penelitian ini, metode analisis deskriptif digunakan untuk menganalisis kuesioner yang telah diberikan kepada responden. Kuesioner yang berisi data balikan responden berkaitan dengan keberterimaan dan kebermanfaatan istilah serapan pada masa pandemi virus korona selanjutnya diolah, dianalisis, dan dijabarkan dalam bentuk tabel.

Metode penyajian hasil analisis data yang digunakan dalam penelitian ini adalah metode formal dan informal. Secara sederhana, menurut Mahsun (2017), Sudaryanto (2018), dan Muhammad (2011), metode formal adalah perumusan dengan menggunakan tanda-tanda atau lambang-lambang, sedangkan metode informal adalah perumusan dengan menggunakan kata-kata biasa, termasuk penggunaan terminologi yang bersifat teknis.

\section{Hasil dan Pembahasan}

Terdapat tiga teknik pemadanan istilah asing yang dapat digunakan yaitu, penerjemahan (langsung dan dengan perekaan), penyerapan (penyerapan dengan penyesuaian ejaan dan lafal, penyerapan dengan penyesuaian ejaan tanpa penyesuaian lafal, dan penyerapan tanpa penyesuaian ejaan sekaligus tanpa penyesuaian lafal), dan gabungan penerjemahan dan penyerapan. Dari hasil analisis data, penulis menemukan kelompok data pemadanan istilah serapan dalam masa pandemi virus korona.

1. Kelompok data (I)

kontaminasi silang (cross contamination), percikan (droplet), pelindung muka (face shield), pelandaian kurva (flattening the curve), penyanitasi tangan (hand sanitizer), alat pelindung wajah (hazmat mask), Alat Pelindung Diri-APD (hazmat suit), kekebalan kelompok (herd immunity), kasus impor (imported case), penularan lokal (local transmission), karantina wilayah (lockdown), masker (mask), tes serentak (massive test), pandemi (pandemic), protokol (protocol), kenormalan baru (new normal), penjarakan fisik (physical distancing), uji cepat (rapid test), penyaringan (screening), isolasi mandiri (self isolation), karantina mandiri (self quarantine), penjarakan sosial (social distancing), penjarakan media sosial 
Helmy, L. M., Mahsun, M \& Burhanuddin, B., (2021). Techniques for Absorption into Indonesian and the Acceptance of Loan Words Related to Covid-19: Socioterminology Approach. LITE: Jurnal Bahasa, Sastra, dan Budaya 17 (2), 139-149. https://doi.org/10.33633/lite.v17i2.4761

(social media distancing), pembatasan sosial (social restriction), penyintas (survivor), uji usap (tes swab), pistol termo (thermo gun), tes usap tenggorokan (throat swab test), penelusuran; pelacakan (tracing), spesimen (specimen), ventilator (ventilator), Kerja dari Rumah-KDR (Work from Home), Kerja dari Kantor (Work from Office)

2. Kelompok data (II)

antiseptik (antiseptic), klorokuin (chloroquine), suspek korona (corona supect), dekontaminasi (decontamination), disinfektan (disinfectant), inkubasi (incubation), isolasi (isolation), respirator (respirator), zoonosis (zoonosis)

3. Kelompok data (III)

penyakit koronavirus (coronavirus disease), uji strep cepat (rapid strep test)

Berdasarkan hasil analisis terhadap ketiga jenis data di atas, dapat dikatakan bahwa kelompok data (I) termasuk kelompok istilah yang dipadankan menggunakan kaidah penerjemahan, data (II) termasuk kelompok istilah yang dipadankan menggunakan kaidah penyerapan, dan data (III) termasuk kelompok istilah yang dipadankan menggunakan kaidan gabungan penerjemahan dan penyerapan.

\subsection{Kaidah Pemadanan Teknik Penerjemahan}

Dalam kelompok data I, data (1) berupa istilah asing cross contamination yang dipadankan dengan istilah kontaminasi silang. Pemadanan istilah ini menggunakan teknik penerjemahan yakni penerjemahan langsung. Proses penerjemahan tampak pada kata cross yang di dalam bahasa Inggris berarti silang dan kata contamination yang berarti kontaminasi. Data (2) istilah asing droplet dipadankan dengan istilah percikan. Proses pemadanan istilah ini menggunakan teknik penerjemahan langsung. Teknik penerjemahan tampak pada kata droplet yang dalam bahasa Inggris berarti tetesan kecil kemudian dipadankan dengan kata percikan.

Data (3) adalah istilah asing face shield dipadankan dengan istilah pelindung muka. Proses pemadanan istilah ini menggunakan teknik penerjemahan langsung. Hal ini tampak pada kata face yang di dalam bahasa Inggris berarti muka dan shield yang di dalam bahasa Inggris berarti pelindung. Data (4) istilah asing flattening the curve dipadankan dengan istilah pelandaian kurva. Istilah ini dipadankan menggunakan teknik penerjemahan langsung. Hal ini tampak pada kata flattening yang di dalam bahasa Inggris berarti pelandaian dan curve yang berarti kurva.

Data (5) yakni istilah asing hand sanitizier yang dipadankan dengan istilah penyanitasi tangan. Istilah ini dipadankan dengan menggunakan teknik penerjemahan langsung. Hal ini terlihat pada kata hand yang di dalam bahasa Indonesia berarti tangan dan sanitizier yang di dalam bahasa Indonesia berarti penyanitasi. Data (6) adalah istilah asing hazmat mask yang dipadankan dengan istilah alat pelindung wajah. Proses pemadanan istilah ini menggunakan teknik penerjemahan langsung. Hal ini dapat dibuktikan pada kata hazmat yang berarti perlengkapan pelindung pribadi dan kata mask yang berarti masker. Gabungan kedua kata tersebut kemudian membentuk istilah hazmat mask yang dipadankan dengan istilah alat pelindung wajah.

Data (7) adalah istilah asing hazmat suit yang dipadankan dengan istilah alat pelindung diri. Proses pemadanan istilah ini menggunakan teknik penerjemahan langsung. Hal ini dapat dibuktikan pada kata hazmat yang berarti perlengkapan pelindung pribadi dan kata suit yang berarti diri. Data (8) istilah asing herd immunity dipadankan dengan istilah kekebalan kelompok. Proses pemadanan istilah ini menggunakan teknik penerjemahan langsung. Hal ini tampak pada kata herd yang di dalam bahasa Indonesia berarti kawanan atau kelompok dan immunity yang berarti kekebalan.

Penulis menjumpai data (9) yaitu istilah asing imported case yang dipadankan dengan istilah kasus impor. Proses pemadanan istilah ini menggunakan teknik penerjemahan langsung. Hal ini 
Helmy, L. M., Mahsun, M \& Burhanuddin, B., (2021). Techniques for Absorption into Indonesian and the Acceptance of Loan Words Related to Covid-19: Socioterminology Approach. LITE: Jurnal Bahasa, Sastra, dan Budaya 17 (2), 139-149. https://doi.org/10.33633/lite.v17i2.4761

terlihat pada kata imported yang berarti impor dan case yang berarti kasus. Data (10) istilah asing local transmission dipadankan dengan istilah transmisi lokal. Proses pemadanan istilah ini menggunakan teknik penerjemahan langsung. Hal ini terlihat pada kata transmission yang berarti penularan dan kata local yang berarti lokal.

Data (11) adalah istilah asing lockdown yang dipadankan dengan istilah karantina wilayah. Proses pemadanan istilah ini menggunakan teknik penerjemahan langsung. Hal ini terlihat pada istilah lockdown yang jika diterjemahkan langsung berarti kuncitara yang serupa dengan istilah karantina wilayah. Data (12) adalah mask yang dipadankan dengan istilah masker. Proses pemadanan istilah ini menggunakan teknik penerjemahan langsung. Hal ini terlihat pada kata mask yang di dalam bahasa Indonesia berarti masker.

Data (13) adalah istilah asing massive test yang dipadankan dengan istilah tes serentak. Proses pemadanan istilah ini menggunakan teknik penerjemahan langsung. Hal ini terlihat pada kata test yang di dalam bahasa Indonesia berarti tes dan massive yang jika diterjemahkan ke dalam bahasa Indonesia dapat berarti serentak dan besar-besaran. Data (14) adalah istilah asing pandemic yang dipadankan dengan istilah pandemi. Proses pemadanan istilah ini menggunakan teknik penerjemahan langsung. Hal ini terlihat pada kata pandemic yang jika diterjemahkan ke dalam bahasa Indonesia berarti pandemi.

Data (15) berupa istilah asing protocol yang dipadankan dengan istilah protokol. Proses pemadanan istilah ini menggunakan teknik penerjemahan langsung. Hal ini terlihat pada kata protocol yang jika diterjemahkan ke dalam bahasa Indonesia berarti protokol. Data (16) adalah frasa new normal yang dipadankan dengan istilah kenormalan baru. Proses pemadanan istilah ini menggunakan teknik penerjemahan langsung. Hal ini terlihat pada kata new yang jika diterjemahkan ke dalam bahasa Indonesia menjadi baru dan normal yang di dalam konteks istilah ini dalam bahasa Indonesia diterjemahkan dengan istilah kenormalan.

Data (17) adalah istilah asing physical distancing yang dipadankan dengan istilah penjarakan fisik. Proses pemadanan istilah ini menggunakan teknik penerjemahan langsung. Hal ini tampak pada kata physical yang apabila diterjemahkan ke dalam bahasa Indonesia berarti fisik dan distancing yang berarti penjarakan. Data (18) adalah istilah asing rapid test yang dipadankan dengan istilah uji cepat. Proses pemadanan istilah ini menggunakan teknik penerjemahan langsung. Hal ini tampak pada kata rapid yang jika diterjemahkan ke dalam bahasa Indonesia berarti cepat dan kata test yang jika diterjemahkan ke dalam bahasa Indonesia berarti uji.

Data (19) adalah istilah asing screening yang dipadankan dengan istilah penyaringan. Proses pemadanan istilah ini menggunakan teknik penerjemahan langsung. Hal ini dapat dibuktikan jika istilah asing screening diterjemahkan ke dalam bahasa Indonesia menjadi istilah penyaringan. Di data (20), istilah asing self isolation dipadankan dengan istilah isolasi mandiri. Proses pemadanan istilah ini menggunakan teknik penerjemahan langsung. Hal ini dapat dibuktikan pada kata self yang jika diterjemahkan ke dalam bahasa Indonesia berarti diri atau mandiri dan kata isolation yang diterjemahkan ke dalam bahasa Indonesia berarti isolasi.

Di data (21), penulis menjumpai istilah asing self quarantine yang dipadankan dengan istilah karantina mandiri. Proses pemadanan istilah ini menggunakan teknik penerjemahan langsung. Hal ini dapat dibuktikan pada kata self yang jika diterjemahkan ke dalam bahasa Indonesia berarti diri atau mandiri dan kata quarantine yang diterjemahkan ke dalam bahasa Indonesia berarti karantina.

Data (22) adalah istilah asing social distancing yang dipadankan dengan istilah penjarakan sosial. Proses pemadanan istilah ini menggunakan teknik penerjemahan langsung. Hal ini tampak pada kata social yang apabila diterjemahkan ke dalam bahasa Indonesia berarti sosial dan distancing berarti penjarakan. 
Helmy, L. M., Mahsun, M \& Burhanuddin, B., (2021). Techniques for Absorption into Indonesian and the Acceptance of Loan Words Related to Covid-19: Socioterminology Approach. LITE: Jurnal Bahasa, Sastra, dan Budaya 17 (2), 139-149. https://doi.org/10.33633/lite.v17i2.4761

Data (23) yang merupakan istilah asing social media distancing dipadankan dengan istilah penjarakan media sosial. Proses pemadanan istilah ini menggunakan teknik penerjemahan langsung. Hal ini tampak pada kata social yang apabila diterjemahkan ke dalam bahasa Indonesia berarti sosial, kata media berarti media, dan distancing yang berarti penjarakan. Di data (24), penulis menjumpai istilah asing istilah asing social restriction yang dipadankan dengan istilah pembatasan sosial. Proses pemadanan istilah ini menggunakan teknik penerjemahan langsung. Hal ini tampak pada kata social yang apabila diterjemahkan ke dalam bahasa Indonesia berarti sosial dan restriction berarti pembatasan atau larangan.

Data (25) adalah istilah asing survivor yang dipadankan dengan istilah penyintas. Proses pemadanan istilah ini menggunakan teknik penerjemahan langsung. Hal ini dapat dibuktikan bahwa istilah asing survivor jika diterjemahkan ke dalam bahasa Indonesia menjadi penyintas. Data (26) adalah istilah asing swab test yang dipadankan dengan istilah uji usap. Proses pemadanan istilah ini menggunakan teknik penerjemahan langsung. Hal ini tampak pada kata swab yang jika diterjemahkan ke dalam bahasa Indonesia berarti usap dan kata test yang jika diterjemahkan ke dalam bahasa Indonesia berarti uji.

Di data (27), penulis menjumpai istilah asing thermo gun yang dipadankan dengan istilah pistol termo. Proses pemadanan istilah ini menggunakan teknik penerjemahan langsung. Hal ini tampak pada kata gun yang jika diterjemahkan ke dalam bahasa Indonesia berarti pistol dan kata thermo yang jika diterjemahkan ke dalam bahasa Indonesia berarti termo. Data (28) ada istilah asing throat swab test yang dipadankan dengan istilah uji usap tenggorokan. Proses pemadanan istilah ini menggunakan teknik penerjemahan langsung. Hal ini tampak pada kata swab yang jika diterjemahkan ke dalam bahasa Indonesia berarti usap, throat yang berarti tenggorokan, dan kata test yang jika diterjemahkan ke dalam bahasa Indonesia berarti uji.

Data (29) adalah istilah asing tracing yang dipadankan dengan istilah penelusuran. Proses pemadanan istilah ini menggunakan teknik penerjemahan langsung. Hal ini dapat dibuktikan jika istilah asing tracing diterjemahkan ke dalam bahasa Indonesia menjadi istilah penelusuran. Di data (30), ada istilah asing specimen yang dipadankan dengan istilah spesimen. Proses pemadanan istilah ini menggunakan teknik penerjemahan yakni penerjemahan langsung. Hal ini dapat dibuktikan bahwa istilah asing specimen jika diterjemahkan ke dalam bahasa Indonesia menjadi spesimen.

Dalam data (31), istilah asing ventilator dipadankan dengan istilah ventilator. Proses pemadanan istilah ini menggunakan teknik penerjemahan langsung. Hal ini dapat dibuktikan jika ventilator diterjemahkan ke dalam bahasa Indonesia menjadi ventilator. Data (32) adalah istilah asing work from home yang dipadankan dengan istilah bekerja dari rumah. Proses pemadanan istilah ini menggunakan teknik penerjemahan langsung. Hal ini tampak pada kata work yang jika diterjemahkan ke dalam bahasa Indonesia berarti bekerja, from yang berarti dari, dan kata home yang berarti rumah. Di data (33), istilah asing work from office dipadankan dengan istilah bekerja dari rumah. Proses pemadanan istilah ini menggunakan teknik penerjemahan langsung. Hal ini dapat dibuktikan pada kata work yang jika diterjemahkan ke dalam bahasa Indonesia berarti bekerja, from yang berarti dari, dan kata office yang berarti kantor.

\subsection{Kaidah Pemadanan Teknik Penyerapan}

Data (1) adalah istilah asing antiseptic yang kemudian dipadankan dengan istilah antiseptik menggunakan proses pemadanan yakni teknik penyerapan. Teknik penyerapan yang digunakan ialah penyerapan dengan penyesuaian ejaan tanpa penyesuaian lafal. Hal ini mengacu kepada kaidah penyerapan apabila istilah asing berupa sufiks -ic diserap ke dalam bahasa Indonesia akan berubah menjadi -ik. Di data (2), chloroquin dipadankan dengan istilah klorokuin. Proses pemadanan istilah ini menggunakan teknik penyerapan yaitu penyerapan dengan penyesuaian ejaan 
Helmy, L. M., Mahsun, M \& Burhanuddin, B., (2021). Techniques for Absorption into Indonesian and the Acceptance of Loan Words Related to Covid-19: Socioterminology Approach. LITE: Jurnal Bahasa, Sastra, dan Budaya 17 (2), 139-149. https://doi.org/10.33633/lite.v17i2.4761

tanpa penyesuaian lafal. Hal ini berpedoman pada kaidah penyerapan apabila cch dan ch di muka $a, o$, dan konsonan menjadi $k$.

Di data (3), istilah asing Corona suspect dipadankan dengan istilah suspek korona. Proses pemadanan pada istilah ini menggunakan teknik penyerapan yakni penyerapan dengan penyesuaian ejaan tanpa penyesuaian lafal. Hal ini berpedoman pada kaidah penyerapan $c$ di muka $a$, $u, o$, dan konsonan menjadi $k$ dan sufiks $-c t$ dalam bahasa asing diserap menjadi $k$. Di data (4), istilah asing Coronavirus dipadankan dengan istilah virus korona. Proses pemadanan istilah ini menggunakan teknik penyerapan yakni penyerapan dengan penyesuaian ejaan tanpa penyesuaian lafal. Hal ini mengacu pada kaidah penyerapan $c$ di muka $a, u, o$, dan konsonan menjadi $k$.

Data (5) adalah istilah asing decontamination dipadankan dengan istilah dekontaminasi. Proses pemadanan istilah ini menggunakan teknik penyerapan yakni penyerapan dengan penyesuaian ejaan dan penyesuaian lafal. Hal ini mengacu pada kaidah penyerapan apabila $c c$ di muka $o, u$, dan konsonan menjadi $k$ serta sufiks -ion menjadi - asi dalam bahasa Indonesia. Data (6) adalah disinfectant dipadankan menjadi disinfektan. Proses pemadanan istilah ini menggunakan teknik penyerapan yaknik penyerapan dengan penyesuaian ejaan tanpa penyesuaian lafal. Proses penyerapan ini berpedoman pada kaidah $c t$ di muka menjadi konsonan $k$ dan sufiks -ant berubah menjadi -an dalam bahasa Indionesia.

Di data (7), penulis menjumpai istilah asing incubation yang dipadankan dengan istilah inkubasi. Proses pemadanan istilah ini menggunakan teknik penyerapan yakni penyerapan dengan penyesuaian ejaan dan penyesuaian lafal. Hal ini seturut dengan kaidah penyerapan sufiks -ion menjadi - asi dalam bahasa Indonesia. Kaidah tersebut juga berimplikasi terhadap penyesuaian lafal. Data (8) istilah asing isolation yang dipadankan dengan istilah isolasi. Proses pemadanan istilah ini menggunakan teknik penyerapan yakni penyerapan dengan penyesuaian ejaan dan penyesuaian lafal. Hal ini seturut dengan kaidah penyerapan apabila sufiks -ion menjadi -asi dalam bahasa Indonesia. Kaidah tersebut juga berimplikasi terhadap penyesuaian lafal.

Di data (9), istilah asing respirator dipadankan dengan istilah respirator. Proses pemadanan istilah ini menggunakan teknik penyerapan yakni penyerapan tanpa penyesuaian ejaan dan lafal. Istilah asing respirator diserap secara utuh tanpa pengubahan ejaan dan lafal. Di data (10), istilah asing zoonosis dipadankan dengan istilah zoonosis. Proses pemadanan istilah ini menggunakan teknik penyerapan yakni penyerapan tanpa penyesuaian ejaan dan lafal. Istilah asing zoonosis diserap secara utuh tanpa pengubahan ejaan dan lafal.

\subsection{Kaidah Pemadanan Teknik Gabungan Penerjemahan dan Penyerapan}

Data (1) Coronavirus disease dipadankan dengan istilah penyakit koronavirus. Proses pemadanan istilah ini menggunakan teknik gabungan penerjemahan dan penyerapan. Penyerapan tampak pada pada kata Coronavirus yang dipandakan dengan istilah Koronavirus yang dipadankan berdasarkan kaidah penyerapan apabila $c$ di muka $a, u, o$, dan konsonan menjadi $k$. Selanjutnya, penerjemahan dilakukan pada kata disease yang diterjemahkan menjadi kata penyakit. Di data (2), penulis menjumpai istilah asing rapid strep test yang dipadankan dengan istilah uji strep cepat. Proses pemadanan istilah ini menggunakan teknik gabungan penerjemahan dan penyerapan. Teknik penyerapan tampak pada kata strep yang diserap ke dalam bahasa Indonesia menjadi kata strep. Selanjutnya, teknik penerjemahan tampak pada kata rapid dan test yang jika diterjemahkan ke dalam bahasa Indonesia berarti uji dan cepat. Untuk menunjukkan tingkat keberterimaan dari masing-masing istilah serapan pada masa pandemi Covid-19, penulis menampilkan Tabel 1 yang berisi analisis dari kuesioner yang dibagikan ke responden. 
Helmy, L. M., Mahsun, M \& Burhanuddin, B., (2021). Techniques for Absorption into Indonesian and the Acceptance of Loan Words Related to Covid-19: Socioterminology Approach. LITE: Jurnal Bahasa, Sastra, dan Budaya 17 (2), 139-149. https://doi.org/10.33633/lite.v17i2.4761

Tabel 1: Keberterimaan Istilah Serapan dalam Masa Pandemi Virus Korona

\begin{tabular}{|c|c|c|c|c|c|}
\hline \multirow{3}{*}{ Istilah Asing } & \multirow{3}{*}{ Padanan Istilah } & \multicolumn{4}{|c|}{ Pilihan Jawaban } \\
\hline & & \multicolumn{2}{|c|}{ Berterima } & \multicolumn{2}{|c|}{ Tidak Berterima } \\
\hline & & $f$ & $(\%)$ & $f$ & $(\%)$ \\
\hline Antiseptict & Antiseptik & 93 & $93 \%$ & 7 & $7 \%$ \\
\hline Chloroquine & Klorokuin & 28 & $28 \%$ & 32 & $32 \%$ \\
\hline Corona Suspect & Suspek Korona & 38 & $38 \%$ & 62 & $62 \%$ \\
\hline Corona Virus & Virus Korona & 66 & $66 \%$ & 36 & $36 \%$ \\
\hline Coronavirus & Penyakit Korona virus & 22 & $22 \%$ & 78 & $78 \%$ \\
\hline \multicolumn{6}{|l|}{ Disease } \\
\hline Cross Contamination & Kontaminasi Silang & 17 & $17 \%$ & 83 & $83 \%$ \\
\hline Decontamination & Dekontaminasi & 41 & $41 \%$ & 59 & $59 \%$ \\
\hline Disinfectant & Disinfektan & 72 & $72 \%$ & 28 & $28 \%$ \\
\hline Droplet & Percikan & 5 & $5 \%$ & 95 & $95 \%$ \\
\hline Face Shield & Pelindung Muka & 23 & $23 \%$ & 77 & $77 \%$ \\
\hline Flattening the Curve & Pelandaian Kurva & 5 & $5 \%$ & 95 & $95 \%$ \\
\hline Hand Sanitizer & Penyanitasi Tangan & 6 & $6 \%$ & 94 & $94 \%$ \\
\hline Hazmat Mask & Alat Pelindung Wajah & 10 & $10 \%$ & 90 & $90 \%$ \\
\hline Hazmat Suit & Alat Pelindung Diri & 28 & $28 \%$ & 72 & $72 \%$ \\
\hline Herd Immunity & Kekebalan Kelompok & 8 & $8 \%$ & 92 & $92 \%$ \\
\hline Imported Case & Kasus Impor & 38 & $38 \%$ & 62 & $62 \%$ \\
\hline Incubation & Inkubasi & 87 & $87 \%$ & 13 & $13 \%$ \\
\hline Isloation & Isolasi & 90 & $90 \%$ & 10 & $10 \%$ \\
\hline Local Transmission & Penularan Lokal & 39 & $39 \%$ & 61 & $61 \%$ \\
\hline Lockdown & Karantina Wilayah & 5 & $5 \%$ & 95 & $95 \%$ \\
\hline Mask & Masker & 97 & $97 \%$ & 3 & $3 \%$ \\
\hline Massive Test & Tes Serentak & 11 & $11 \%$ & 89 & $89 \%$ \\
\hline New Normal & Kenormalan Baru & 10 & $10 \%$ & 90 & $90 \%$ \\
\hline Pandemic & Pandemi & 93 & $93 \%$ & 7 & $7 \%$ \\
\hline Physical Distancing & Penjarakan Fisik & 15 & $15 \%$ & 85 & $85 \%$ \\
\hline Protocol & Protokol & 88 & $88 \%$ & 12 & $12 \%$ \\
\hline Rapid Strep Test & Uji Strep Cepat & 5 & $5 \%$ & 95 & $95 \%$ \\
\hline Rapid Test & Uji Cepat & 13 & $13 \%$ & 87 & $87 \%$ \\
\hline Respirator & Respirator & 71 & $71 \%$ & 29 & $29 \%$ \\
\hline Screening & Penyaringan & 2 & $2 \%$ & 98 & $98 \%$ \\
\hline Self Isolation & Isolasi Mandiri & 90 & $90 \%$ & 10 & $10 \%$ \\
\hline Self Quarantine & Karantina Mandiri & 83 & $83 \%$ & 17 & $17 \%$ \\
\hline Social Distacing & Penjarakan Sosial & 12 & $12 \%$ & 88 & $88 \%$ \\
\hline Social Media & Penjarakan Media & 2 & $2 \%$ & 98 & $98 \%$ \\
\hline Distancing & Sosial & & & & \\
\hline Social Restriction & Pembatasan Sosial & 18 & $18 \%$ & 82 & $82 \%$ \\
\hline Specimen & Spesimen & 58 & $58 \%$ & 42 & $42 \%$ \\
\hline Survivor & Penyintas & 8 & $8 \%$ & 92 & $92 \%$ \\
\hline Swab Test & Uji Usap & 17 & $17 \%$ & 83 & $83 \%$ \\
\hline Thermo Gun & Pistol Termo & 0 & $0 \%$ & 100 & $100 \%$ \\
\hline Throat Swab Test & Tes Usap Tenggorokan & 7 & $7 \%$ & 93 & $93 \%$ \\
\hline Tracing & Penelusuran; & 35 & $35 \%$ & 65 & $65 \%$ \\
\hline & Pelacakan & & & & \\
\hline Ventilator & Ventilator & 67 & $67 \%$ & 33 & $33 \%$ \\
\hline Work From Home & Kerja Dari Rumah & 71 & $71 \%$ & 29 & $29 \%$ \\
\hline Work From Office & Kerja Dari Kantor & 70 & $70 \%$ & 30 & $30 \%$ \\
\hline Zoonois & Zoonosis & 55 & $55 \%$ & 45 & $45 \%$ \\
\hline \multicolumn{2}{|c|}{ Jumlah } & 1719 & \multicolumn{3}{|c|}{2781} \\
\hline \multicolumn{2}{|c|}{ Rata-rata } & 39 & $39 \%$ & 61 & $61 \%$ \\
\hline
\end{tabular}


Tabel 1 di atas menunjukkan bahwa tingkat keberterimaan istilah serapan dalam masa pandemi virus korona adalah 39\%. Sementara, 61\% menunjukkan tingkat ketidakberterimaan terhadap istilah serapan dalam masa pandemi virus korona. Istilah serapan yang paling tinggi tingkat keberterimaannya yakni istilah masker dengan persentase keberterimaan 97\%. Selanjutnya, istilah yang paling rendah tingkat keberterimaannya yakni istilah pistol termo dengan persentase tingkat ketidakberterimaan $100 \%$.

\section{Simpulan}

Berdasarkan analisis data yang dilakukan terhadap data yang telah dikumpulkan, penulis dapat menyimpulkan beberapa hal, yaitu istilah serapan dalam masa pandemi virus korona dipadankan dengan menggunakan tiga teknik pemadanan istilah, yaitu teknik penerjemahan, teknik penyerapan, serta teknik gabungan penerjemahan dan penyerapan. Terdapat 33 istilah asing yang dipadankan menggunakan teknik penerjemahan yakni penerjemahan langsung. Selanjutnya, 10 istilah asing dipadankan dengan menggunakan teknik penyerapan yang terdiri atas 6 teknik penyerapan dengan penyesuaian ejaan tanpa penyesuaian lafal, 4 teknik penyerapan dengan penyesuaian ejaan dan penyesuaian lafal, 3 teknik penyerapan tanpa penyesuaian ejaan dan penyesuaian lafal. Lalu, terdapat 2 istilah serapan yang dipadankan menggunakan teknik gabungan penerjemahan dan penyerapan. Tingkat keberterimaan istilah serapan dalam masa pandemi virus korona adalah sebanyak 39\% dan 61\% lainnya menunjukkan tingkat ketidakberterimaan terhadap istilah serapan dalam masa pandemi virus korona. Istilah serapan yang paling tinggi tingkat keberterimaannya yakni istilah masker dengan persentase keberterimaan 97\%. Selanjutnya, istilah yang paling rendah tingkat keberterimaannya yakni istilah pistol termo dengan persentase tingkat ketidakberterimaan $100 \%$.

\section{Referensi}

Arifin, Z. (2018). Keterbacaan Terjemahan dan Serapan Istilah-istilah Teknologi Informasi dalam Teks Panduan Komputer HP: Petunjuk Konfiguras. Surakarta: Universitas Muhammadiyah Surakarta.

Astuti, W. (2007). Sikap Bahasa Mahasiswa dan Dosen Terhadap Istilah Terjemahan dan Istilah Serapan Bidang Ekonomi Hasil Mabbim. Humaniora, 67-72.

Chaer, Abdul. (2012). Linguistik Umum. Jakarta: Rineka Cipta.

Darheni, Nani. (2009). Penyerapan Leksikon Asing dalam Bidang Otomotif ke dalam Bahasa Indonesia: Tinjauan Secara Morfologis dan Fonologis. Jurnal Sosioteknologi, 646 - 666.

Darnis, Azhari. (2012). Ketermanfaatan Pedoman Umum Pembentukan Istilah (PUPI) dalam Pembentukan Istilah Bahasa Indonesia. Depok: Universitas Indonesia.

Kridalaksana, Harimurti. (2008). Kamus Linguistik. PT Gramedia Pustaka: Jakarta.

Kridalaksana, Harimurti. (2009). Pembentukan Kata dalam Bahasa Indonesia. Jakarta: PT Gramedia Pustaka Utama.

Mahsun. (2017). Metode Penelitian Bahasa: Tahapan, Strategi, Metode, dan Tekniknya. Depok: Rajawali Press.

Muhammad. (2011). Penelitian Bahasa: Paradigma Kualitatif. Yogyakarta: Liebe Book Press. 
Helmy, L. M., Mahsun, M \& Burhanuddin, B., (2021). Techniques for Absorption into Indonesian and the Acceptance of Loan Words Related to Covid-19: Socioterminology Approach. LITE: Jurnal Bahasa, Sastra, dan Budaya 17 (2), 139-149. https://doi.org/10.33633/lite.v17i2.4761

Mulyanto, Firman. (2017). Buku Lengkap EBI (Ejaan Bahasa Indonesia). Yogyakarta: Laksana.

Pusat Bahasa. (2007). Pedoman Umum Pembentukan Istilah (PUPI). Jakarta: Departemen Pendidikan Nasional.

Qodratillah, Meity Taqdir. (2017). Studi Komparatif tentang Keseragaman Istilah di Bidang Kedokteran dan Keuangan dari Sudut Pembakuan. Depok: Universitas Indonesia.

Sirulhaq, Ahmad; Sukri; Jafar, Syamsinas; dan Burhanuddin. (2018). Questioning "The Great Indonesian Dictionary" (KBBI). Advances in Social Science, Education and Humanities Research (ASSEHR).Volume: 228. (p. 28). London: Atlantis Press.

Sudaryanto. (2008). Metode dan Aneka Teknik Analisis Bahasa. Yogyakarta: Sanata Dharma University Press.

Sugiyono. (2019). Metode Penelitian Kuantitatif, Kualitatif, dan R\&D. Bandung: Penerbit Alfabeta.

Wardani, Vera, dan Nuraiza. (2019). Proses Pemakaian Kata Serapan dan Istilah Asing dalam Opini pada Harian Serambi Indonesia. Jurnal Riset Sains, 57-66.

Zaim, M. (2015). Keberterimaan dan Kebermanfaatan Istilah Serapan Kata Asing dalam Bidang Teknologi Informasi oleh Penutur Bahasa Indonesia. Padang: Universitas Negeri Padang.

https://kbbi.kemdikbud.go.id/entri/kata\%20serapan 